\title{
THE PERCEPTIONS OF LIBYAN EFL UNIVERSITY STUDENTS TOWARDS THE USE OF GROUP WORK IN THEIR SPEAKING CLASSES
}

\author{
Imad Waragh ${ }^{1}$, \\ Hamdi Suwaed $^{2 i}$ \\ ${ }^{1}$ Dr., University of Al-Zintan, \\ Libya \\ ${ }^{2}$ University of Subratha, \\ Libya
}

\begin{abstract}
:
Group work is believed to be one of the possible solutions to the problem of dealing with large number of students within one speaking class. However, how students perceive group work in their EFL speaking classes is an area that needs to be researched. This study looks at how students perceive group work in their speaking classes and their preference of being given a specific role in a given speaking task that involves working in a group. A questionnaire has been distributed to 42 students to highlight their perceptions towards group work. Results from this study revealed that EFL students seem to like the idea of working in groups in their speaking classes as they reported a number of benefits that they gain when they work in groups, for example, they feel more independent, they have a chance to share ideas, and they speak English in most of the time in the class. However, a number of drawbacks have been also reported by the students, for example, the domination of one student in the group, some students find it difficult to work in a group of mixed gender, and low level students sometimes feel frustrated to work in group.
\end{abstract}

Keywords: meaning of group work, benefits of group work, and drawbacks of group work

\section{Introduction}

In almost all the training courses and workshops that EFL teachers might attend, promoting 'student - student interaction' (Wichadee, 2007:10) by asking students to work in small or large groups has been the recommended technique that EFL teachers are encouraged to use in their speaking classes. This is due to the fact that the number of

i Correspondence: email maping2012@snnu.edu.cn, enjoy1208@163.com 
students in EFL classes is relatively large and also because working in small and large groups would reduce the level of anxiety that the students might have compared to working as a whole class. In Libyan university classrooms, for example, the number of students per class is about 30 students and giving every student the chance to speak in the speaking class might be a challenge for the speaking teacher. In addition, the time devoted to teach speaking skill is only four hours a week and for students to improve their levels in speaking they will need to use their English in most of the time in their lectures.

Therefore, speaking teachers need to group their students to give them the chance to have sufficient time of talking in English. For that, group work has been of great importance not only that it allows the students to interact more in the target language (English), but it also encourages the students to use their English in most of the time in the class. Group work has also the advantage of "preparing the students for their future work" (Burdett, 2003:177). However, the use of group work might have its own drawbacks as EFL students may not perceive group work as a technique that helps them to improve their speaking as one student in the group might dominate the discussion and some students may not like the idea of working in a group of mixed gender.

\section{Theoretical Framework}

\subsection{Definition of Group Work}

Harmer (2003:102) defined group work as the process in which classroom students are divided into small or large groups - depending on the task and the number of learners to perform a given task. Tasks that involve the use of group work in an English speaking class are - for example - debates, discussions, and problem-solving situations (Ur, 1990). The importance of using group work in EFL classes is that group work "provides a context in which individuals help each other; it is a method of helping groups as well as helping individuals" to share ideas, and positively interact with their peers (Brown, 1992).

\subsection{Benefits of Group Work}

Research into the perceptions and attitudes of EFL students towards the use of group work in EFL classes highlighted both the benefits and drawbacks of using group work in EFL classrooms. Burke (2011:88) highlighted a number of advantages of using group work in EFL classes as she points "students who work in groups form a clearer picture of their personality as they have a chance to understand how others see them, group members have more knowledge than an individual and that helps them a lot to perform a given task, and working in a group encourage creativity and help students to 'think out of the box'. Group work can be useful in EFL speaking classes as students can help each other to perform an activity as Alfares (2017) noticed that students were mostly satisfied with working in group in a speaking class as that "enabled them to get help from their peers" and it "provides an opportunity for assistance between group members" (p.251). 


\subsection{Drawbacks of Group Work}

Beebe and Masterson (2003) summarized three main disadvantages of using group work in EFL class rooms as 'less able students' may rely on other members of the group to perform the task. Alfares supports that point as she mentions that participants in her study reported that group work especially in a mixed - level group could be a frustrating experience as "certain students tend to ask their peers for help too many times" (p.252). Another disadvantage of using group work is that one student may dominate the discussion leaving no chance for other students to participate. McCafferty (2006) suggests that giving each student a part (role) to be responsible on in a group activity would minimise the domination of one member and as Dörnyei and Murphey (2003) argues that would make everyone feel involved and his/her participation appreciated. The third disadvantage that Beebe and Masterson (2003) mentions is that agreeing on one opinion in a task that involves working in a group might be a challenging task for the group members.

Several studies highlight the concept that group work is important for speaking classes as (Alfares, 2017; Chiric, 2014). However, this study has given the targeted group of students the chance to express their thoughts about group work by looking for the perceptions that they have towards group work and if they prefer to be given a specific role when they are asked to work in groups. Chiric (2014:1) recommended that allowing the EFL students to provide information on why group work is an interesting technique used by their teachers in some classes and why it is not so interesting for them in some others would provide teachers with the chance to minimize the number of drawbacks when using group work in their teaching.

\section{Methodology}

\subsection{Instrument and Procedure of Data Collection}

In this study a questionnaire was used to collect data to answer the following research question:

- Do EFL students prefer to be given a specific role when working in groups in their speaking classes? and what are the benefits and drawbacks of working in a group?

The questionnaire has been chosen as a tool for data collection because it allows the researchers to cover a relatively large population and findings derived from analysing questionnaires could be generalized (Cohen et al., 2007). Items of the questionnaire were explained to the participants and their answers would be used only for the purpose of the study. Also, the participants were informed that they can withdraw filling the questionnaire at any time. Data collected by using the questionnaire was analyzed using SPSS software.

\subsection{Participants}

The target participants in this study were 42 but only 40 students completed the questionnaire. They were second year EFL students who are doing BA in English at 
Subratha University. The participants are all Libyans, and their mother tongue is Arabic and they are 35 females and 5 males. They are aged 19 to 21.

\section{Findings and Discussion}

This section provides an in-depth discussion of the findings obtained from the analysis. The central purpose of this section is to focus on answering the research question based on the results which have emerged from a quantitative technique. The results are discussed in line with those existing in the literature in relation to the framework and relevant themes emerged from the data. This study aimed at highlighting EFL students' perceptions towards the use of group work in EFL speaking classes. Each section concentrates on a different aspect of group work use as highlighted in the study. The analysis and discussion start by introducing the students' perceptions of having specific role in group work in relation to the research question, followed by the benefits and drawbacks of using group work. This section focuses on interesting findings which are related to the research question.

\subsection{Students' Role in Group Work}

This section analysis and discuss the findings from quantitative data concerning students' perceptions about the use of group work in speaking classes. The data show that 45 most of students prefer to receive specific role in group work. The students' questionnaire was designed in the form of yes, no, not sure. The data gathered are organised in the form of figures supported by descriptions.

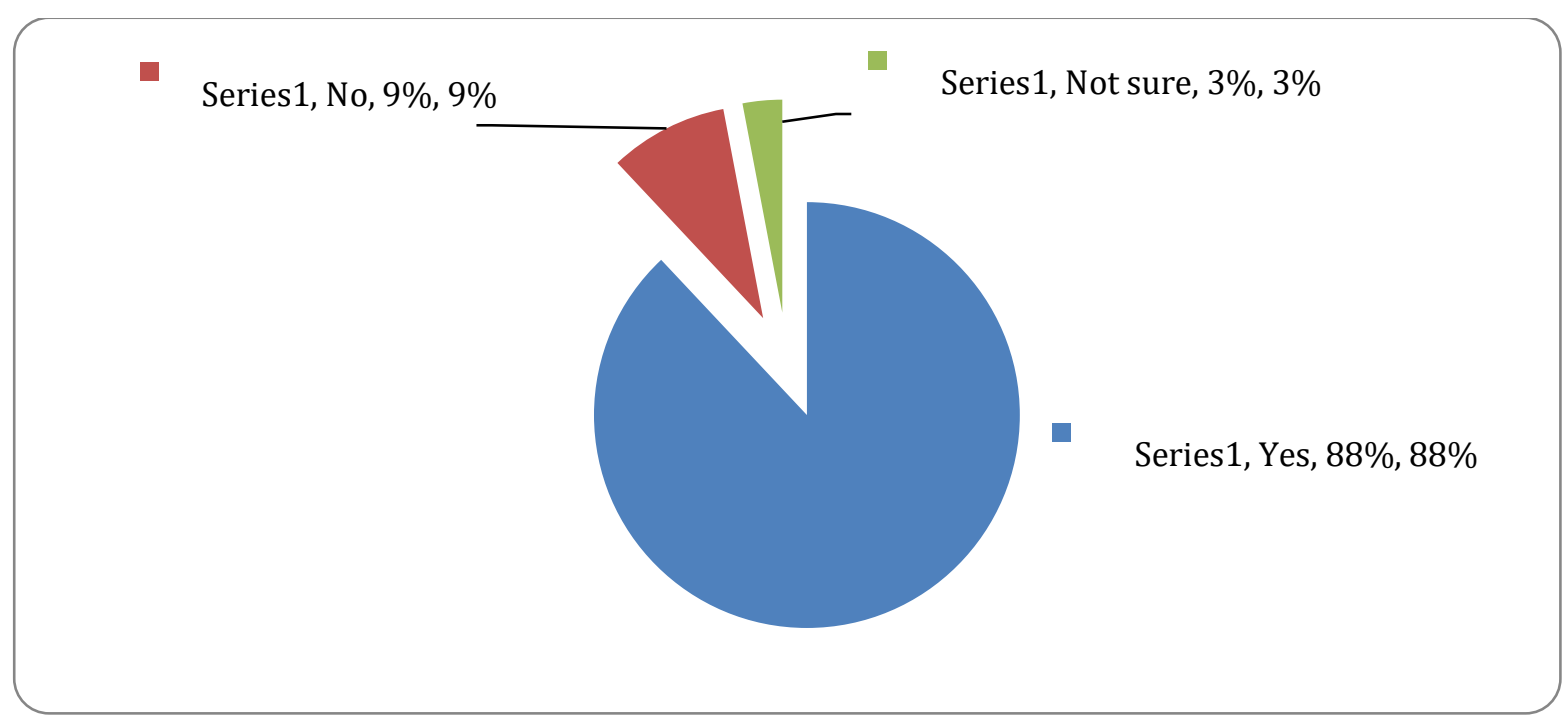

Figure 1: Preference of being given a specific role in GW

Figure 1 summarises the data concerning students' preferences to the role in group work in speaking classes. As can be seen in figure (1), $88 \%$ of the participants preferred to be given a specific role in a group work activity or task, which means that the majority of participants believed that having specific role in group work helped them to become 
more active and responsible learners with confident. This study could help students by giving them the opportunity to be more involved in the process of learning. This implies that the university teachers concerning the role of students in group work that influences students' learning. Burke (2011) argues that 'each student needs to be assigned a role, such as the note take or the group spokesman.

The analysis of data also indicates that $9 \%$ of students did not prefer to have specific role in speaking classes. This shows that a small number of participants preferred to work randomly in group which may effect on their speaking skill. Salas (2005:2) indicates that "for lazy or irresponsible students, this is not a problem because the other members will take over and will make the machine work somehow". It seems that having specific role is not valued by these students because they are not aware of the importance of being given a role in the task. This study suggests the importance of more involvement of students in group work because it may be alternative way of learning when they are giving specific role. Also, it appears that students miss out on the value of working in groups and then they are likely to feel that only learning from their teachers. Therefore, teachers need to consider the value of involving students in group work with specific duty which reflect on their speaking.

Similarly found that the students' responses to this question indicate that $(3 \%)$ of students were not sure if they preferred to work in group work speaking classes or not, which means that these students were not aware of the importance of having specific role in group work. This was confirmed by Burke (2011:87) that "many people cringe and groan when told that they will need to work in a group". It also, seems that some of these students may not have worked in a group before. The findings from this study would highlight the importance of giving each student a role in group work. This could be changed if teachers could be encouraged to attach more value to group work and were prepared to spend the time coaching students in how to work in group task. "One way to overcome group hate is to form realistic expectations of group work" (Burke, 2011:88).

\subsection{Benefits of GW}

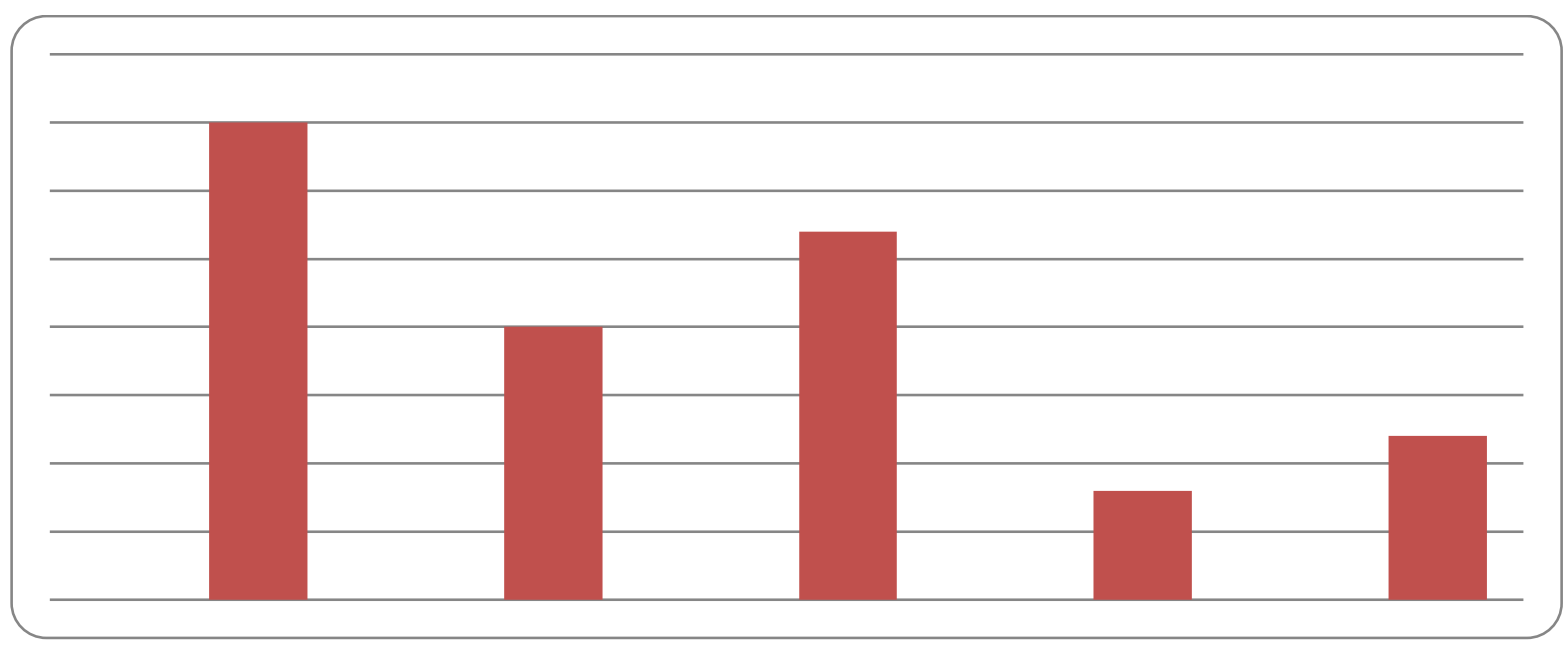

Figure 2: Benefits of GW 
There is a great variation of students' beliefs in responding to benefits of group work. As can be seen in Figure 2, 35\% of the participants reported that they feel more independent when they work in a group to perform a given task, showing that many students were positive about working in groups helping them to become more independent learners. Alfares (2017) Suggests that students should be given chances to be independent in their own learning. In the Libyan context, the majority of students are not involved to work in groups because it is still not familiar to EFL university students, especially in a context where teacher centred is favoured. It also appears that Libyan students work individually in that they do not exchange their thoughts and experiences with peers when they speak. Thus, this study suggests that students need to be more involved in group work in which the level of interaction and independent learning could be increased. Alfares (2017:248) indicates that "groups may allow students to be more independent, because they are encouraged to teach others and also to learn from others". From the above perspectives, it seems clear that these students perceive a group work as an effective method for learning. Thus, more encouragement in this method could lead learners to improve their speaking performance and increase independent learning.

Similarly, the data show that $27 \%$ of students believed that work in groups enable them to have more time to speak English and it seems that these students value speaking English together. Salas (2005:2) argue that "students have to work together for the completion of the task". However, students may speak all at once trying to accomplish their task, and this causes noise. Doff (1991:142)) states that in order "to stop activities getting out of control, it is important to give clear instructions, to give clear defined tasks and to set up a routine so that the students exactly know how and what to do". The implication is that teachers should assign a appropriate time for each student to speak with others in one group based on the activity used.

Next, $20 \%$ of students agreed that working in groups enable them to share their ideas and it appears that group work has a potential impact on students' learning when they discuss their work together. This result is consistent with Alfares (2017) views that students who work in groups in speaking class may get assistance from their peers. Group work becomes a community of learners cooperating with each other in pursuit of learning goals (Brown, 2001). Group work offers an opportunity for cooperative learning and interaction among students because students can exchange and share their information. Group work may have more information than a single individual (Burke, 2011). From this, students need to consider group work as useful resource of information and opportunity for discussion to understand concepts better.

Salas (2005:2) argues that "real cooperation in group work occurs when everyone is aware of his/her responsibility and role and commits himself/herself to accomplish it in the best way possible". Moreover, $13 \%$ of students are more interested to speak in groups, and it can be said that a low percentage of participants feel interested to speak in front of each other in one group. This shows that these students are not positively view group work as useful speaking opportunity and it may be lack of encouragement from their teachers. This result is consistent with a previous study by Alfares (2017:254) that "it appears from 
the data that some language learners do not like to work in groups where certain individuals feel shy and do not participate". Brown (2001:178) also states that "small groups provide opportunities for student initiation, for face-to-face give and take, for negotiation of meaning, and for extended conversational exchanges, and for students adoption of roles that would otherwise be impossible". This implies that teachers need to consider the speaking activities in group work by helping students to view it as method of learning. Alfares (2017) argues that group work can be used to improve oral activities for language learners.

Similarly, $7 \%$ of students prefer to work with other students in one group, which indicates that students are not encouraged by their teachers to work with different students in one group. However, Salas (2005:1) has another opinion that "no one can deny that learners like to work in groups, and if they do a good job, the benefits are many". The current research suggests that students need to work in different groups in one class because it may help them to learn effectively. This implies that Libyan teachers could fully involve students in group work with their guidelines used. Teachers in such educational environments could support students to work together in different groups.

\subsection{Drawbacks of Group Work}

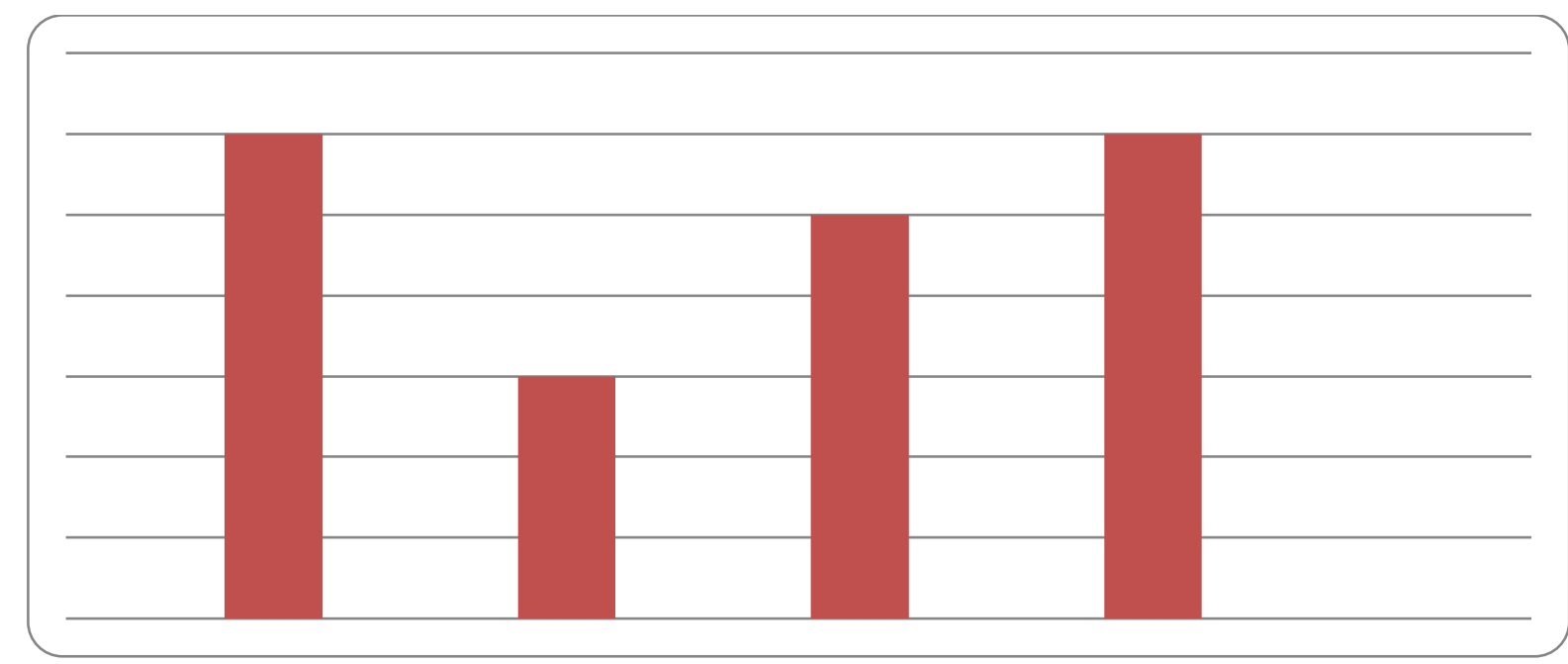

Figure 3: Drawbacks of group work

Although group work has plenty of advantages, there are some disadvantages as current results indicate that $30 \%$ of students have similar view about dominance of number and low level of students' feeling of frustrated. This confirmed by Burke (2011:88') that an individual may dominate the discussion. This result reveals that some students may rely on others to do the work and make decision. "'EFL teachers sometimes lose track of what working in groups really means" (Salas, 2005:1). This leads to members not gaining satisfaction from the group because they feel too alienated in the decision making process (Beebe and Masterson, 2003). One solution to this problem is to make every group member aware of the goals and objectives of the group and assign specific tasks or responsibilities to each member (Beebe and Masterson, 2003). The implication is that 
teachers need to provide students with specific role in group in order to make them satisfied.

Regarding the students' view of group work, 25\% of the participants have difficulties to agree on one opinion. Most students do not like conflict and attempt to avoid it by agreeing to the majority opinion, the individual may agree to a bad solution just to avoid conflict (Beebe and Masterson, 2003). Libyan teachers need to bear in mind this as important factor. Burke (2011:88) also stresses that "there may be pressure from the group to conform to the majority opinion and most people do not like conflict and attempt to avoid it when possible". The implication is that teachers need to manage conflict and disagreements among students in one group.

The data also indicate that $15 \%$ of students did not prefer to work as mix gender, which indicates that mixing male and female in one group may has a potential impact on their role and learning. This makes it unlikely that they will feel comfortable and confident in group work. Previous research by Alfares (2017:254) highlights that "learners explained that some learning-related and emotional barriers were encountered in GW". Burke (2011) also states that simply some students have personality conflicts. Some students may refuse to work with others (Taqi and Al-Nouh, 2014). Therefore, Libyan teachers could provide a classroom learning environment that supports speaking skills by dividing students into groups based on their interest to work together, taking into consideration the cultural issues. This study suggests, as one strategy, that mix gender in the same classroom could be distributed into different groups. This may help these students to work together in order to improve their speaking skills. Consequently, these Libyan tutors need to consider this issue when group work is used. For example, Libyan students could be taught about the purpose of using group work and how it could improve their learning in order to make them more comfortable.

\section{Conclusion}

This study has attempted to find out the perceptions that EFL students have towards the use of group work in speaking classes. It is found that group work is perceived as a way the makes the students feel more independent and it gives them the chance to speak more in the target language (English). However, it is also reported that working in groups may allow one student to dominate the discussion and low-level students may feel frustrated to work in the group. All in all, it can be said that group work can always achieve good results if the teacher manages to give every student a role in the group so that every student feel involved.

\section{Conflict of Interest Statement}

The authors whose names are listed below certify that they have no conflicts of interest. The authors also certify that this paper has not been published elsewhere or being considered for publication in any other journals. 


\begin{abstract}
About the Authors
Dr. Imad Waragh is a lecturer at the University of Al-Zintan and he has a PhD in TESOL from the University of Sunderland, UK. emadwaragh@gmail.com

Hamdi Suwaed is a lecturer assistant at University of Subratha and he has Master in Education from Glasgow University, UK. suwaed2014@gmail.com
\end{abstract}

\title{
References
}

Alfares, N. (2017). Benefits and Difficulties of Learning in Group Work in EFL Classes in Saudi Arabia. English Language Teaching Journal. Vol, 10, No, 7.

Al Nouh A., Taqil H. (2014). Effect of Group Work on EFL Students' Attitudes and Learning in Higher Education. Journal of Education and Learning. Vol, 3, No, 2.

Beebe S., Masterson, T. (2003). Communicating in small groups. Pearson Education Inc, Boston, Massachusetts.

Burdett J. (2003). Making groups work: University Students' Perceptions. International Education Journal. Vol 4, No 3.

Brown, H. D. (1994). Teaching by principles: An interactive approach to language pedagogy. Upper Saddle River, Prentice Hall Regents.

Burke, A. (2011). Group Work: How to Use Groups Effectively. The Journal of Effective Teaching, Vol, 11, No, 2.

Chiriac E. (2014). Group work as an incentive for learning -Students' experience of group work. Educational Psychology Journal. Vol 5,

Cohen, L., Manion L., Morrison K. (2007). Research Methods in Education. Sixth edition. New York, Routledge.

Doff A. (1991). Teach English: a training course for teachers. New York, Cambridge University Press.

Dörnyei Z., Murphey T. (2003). Group Dynamics in the Language Classroom. Cambridge University Press, Cambridge.

Harmer J. (2003). The Practice of English Language Teaching. Oxford, Longman.

McCafferty G., Jacobs, M., DaSilva I. (2006). Cooperative Learning and Second Language Teaching. Cambridge, Cambridge University Press.

Salas M. (2005). Grouping techniques in EFL classrooms. Actualidades Investigativas en Educación. Vol 5.

Ur, P. (1990). Discussions that work: task-centred fluency practice. New York, Cambridge University Press.

Wichadee, S. (2007). The effect of cooperative learning on English reading skills and attitudes of the first-year students at Bangkok University. 29-30. 
Imad Waragh, Hamdi Suwaed

THE PERCEPTIONS OF LIBYAN EFL UNIVERSITY STUDENTS

TOWARDS THE USE OF GROUP IN THEIR SPEAKING CLASSES

Creative Commons licensing terms

Authors will retain the copyright of their published articles agreeing that a Creative Commons Attribution 4.0 International License (CC BY 4.0) terms will be applied to their work. Under the terms of this license, no permission is required from the author(s) or publisher for members of the community to copy, distribute, transmit or adapt the article content, providing a proper, prominent and unambiguous attribution to the authors in a manner that makes clear that the materials are being reused under permission of a Creative Commons License. Views, opinions, and conclusions expressed in this research article are views, opinions and conclusions of the author(s). Open Access Publishing Group and European Journal of English Language Teaching shall not be responsible or answerable for any loss, damage or liability caused in relation to/arising out of conflict of interests, copyright violations and inappropriate or inaccurate use of any kind content related or integrated on the research work. All the published works are meeting the Open Access Publishing requirements and can be freely accessed, shared, modified, distributed and used in educational, commercial and non-commercial purposes under a Creative Commons Attribution 4.0 International License (CC BY 4.0). 